\title{
The Use of AHP within GIS in Selecting Potential Sites for Water Harvesting Sites in the Azraq Basin一Jordan
}

\author{
Abdel Rahman Al-shabeeb \\ Department of Geographic Information System and Remote Sensing, Institute of Earth and Environmental \\ Sciences, Al Al-Bayt University, Mafraq, Jordan \\ Email: abd.alshabeeb@aabu.edu.jo
}

Received 18 January 2016; accepted 20 February 2016; published 23 February 2016

Copyright (C) 2016 by author and Scientific Research Publishing Inc.

This work is licensed under the Creative Commons Attribution International License (CC BY). http://creativecommons.org/licenses/by/4.0/

(c) (i) Open Access

\section{Abstract}

The identification of potential sites for water harvesting is an important step towards maximizing water availability and land productivity in the arid and semi-arid areas. This research aimed to select the optimum sites for water harvesting in the Azraq basin of Jordan through the use of GIS techniques. The Azraq basin is characterized by flash floods that involve large quantities of runoff. The selection criteria in this research were based on six parameters identified based on an extensive literature review. Five experts were then asked to evaluate the importance of each criterion. The consistency ratio between the experts opinions was evaluated using the pairwise comparison method and a final weight was computed for each criterion. A water harvesting suitability map was then generated following the weighted linear combination (WLC) method. The sites that are not suitable for water harvesting within the study area were identified and eliminated following the Boolean method, and final water harvesting suitability map was generated. Finally, the findings of this research can be used to assist in the efficient planning of the water resources management to ensure a sustainable development of the water in Jordan and in other areas suffering from water shortages.

\section{Keywords}

AHP, GIS, Water Harvesting, Azraq Basin, Jordan

\section{Introduction}

Water, is one of the most important resources in Jordan and is attracting an ever increasing demands from

How to cite this paper: Al-shabeeb, A.R. (2016) The Use of AHP within GIS in Selecting Potential Sites for Water Harvesting Sites in the Azraq Basin-Jordan. Journal of Geographic Information System, 8, 73-88. 
agricultural and domestic users. Jordan is one the poorest four countries in the world in water resource. Jordanians use about $150 \mathrm{~m}^{3} /$ person/year, compared with a global average at about $1000 \mathrm{~m}^{3} /$ person/year. According to the Jordan Ministry of Environment [2015], the water scarcity in Jordan is known to be the most important constraints to the Jordan growth and development [1].

Water harvesting techniques can be used to capture and efficiently utilize rainwater runoff to maintain sustainable development of the water in Jordan.

GIS plays a key role in maintaining data and analyzing optimal locations. GIS is a tool that reduces time and cost of the site selection and provides a digital data bank for future monitoring program of the selected sites.

Multi Criteria Decision Analysis (MCDA) in GIS environmental is used to combine layers of spatial data representing the criteria and to specify how the layers are combined. The Analytical Hierarchy Process (AHP) is a method of MCDA that is implemented within GIS, which defines weights for criteria selected.

The use of GIS for identifying the optimum sites for water harvesting schemes has been addressed in many studies [2]-[8].

\section{Research Methodology}

The methodology used to select sites for locating suitable water harvesting zones in selected areas of the Azraq basin of Jordan is shown in Figure 1.

\subsection{Study Area}

The Azraq Basin is located in the Northern and central parts of Jordan (Figure 2), with an estimated area of more than 11,052 $\mathrm{km}^{2}$. The study area is described to has hot, dry summers and cold winters. Rainfall is in the form of uneven storms of high intensity and short duration; evaporation in this study area is very high.

\subsection{Selection Criteria Methods}

MCDA technique is important for water resources management, which involves choosing criteria and decision options [9]. Several methods of MCDA have been implemented in the GIS environment.

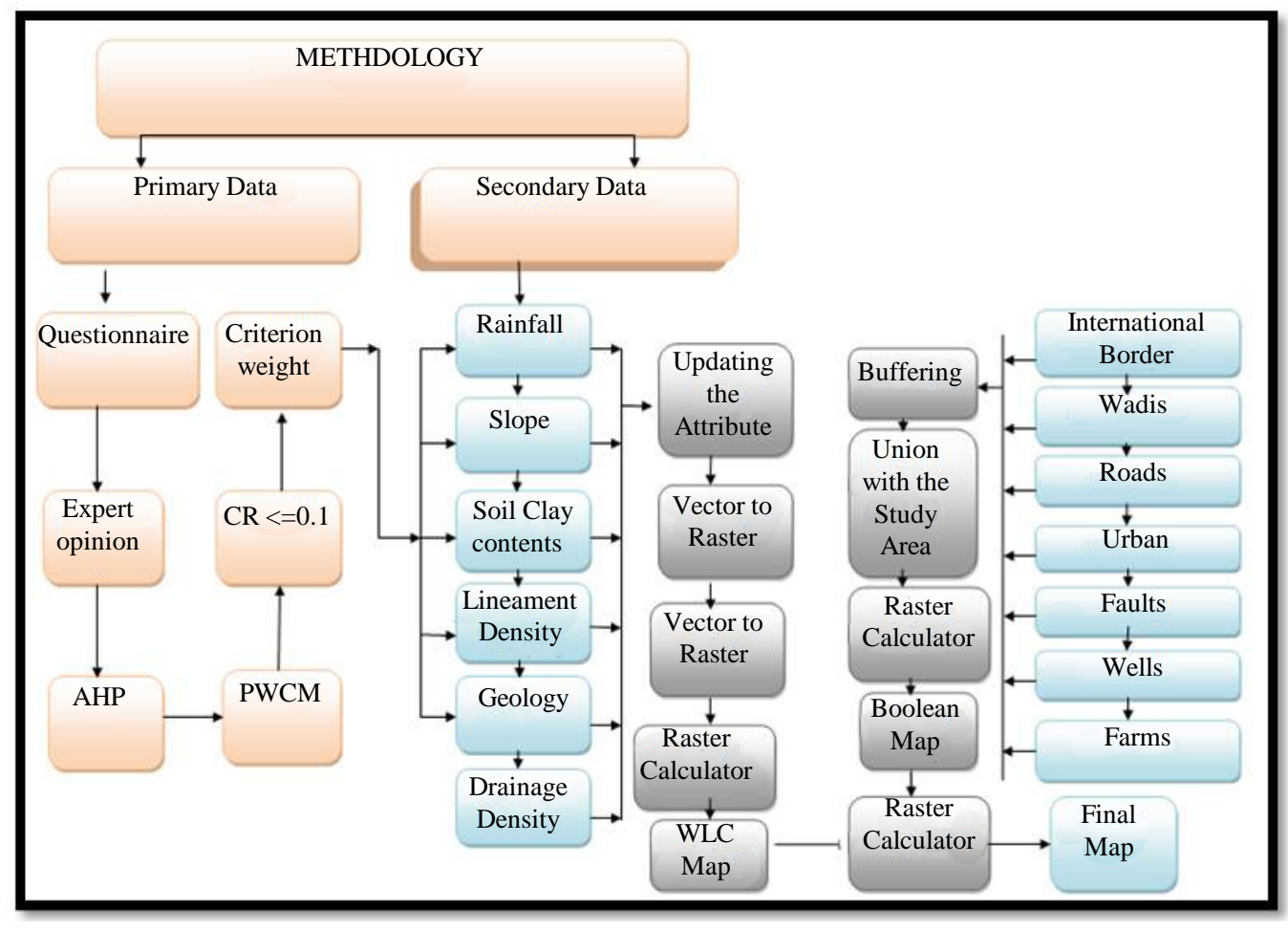

Figure 1. Flowchart of the methodology used in this research. 


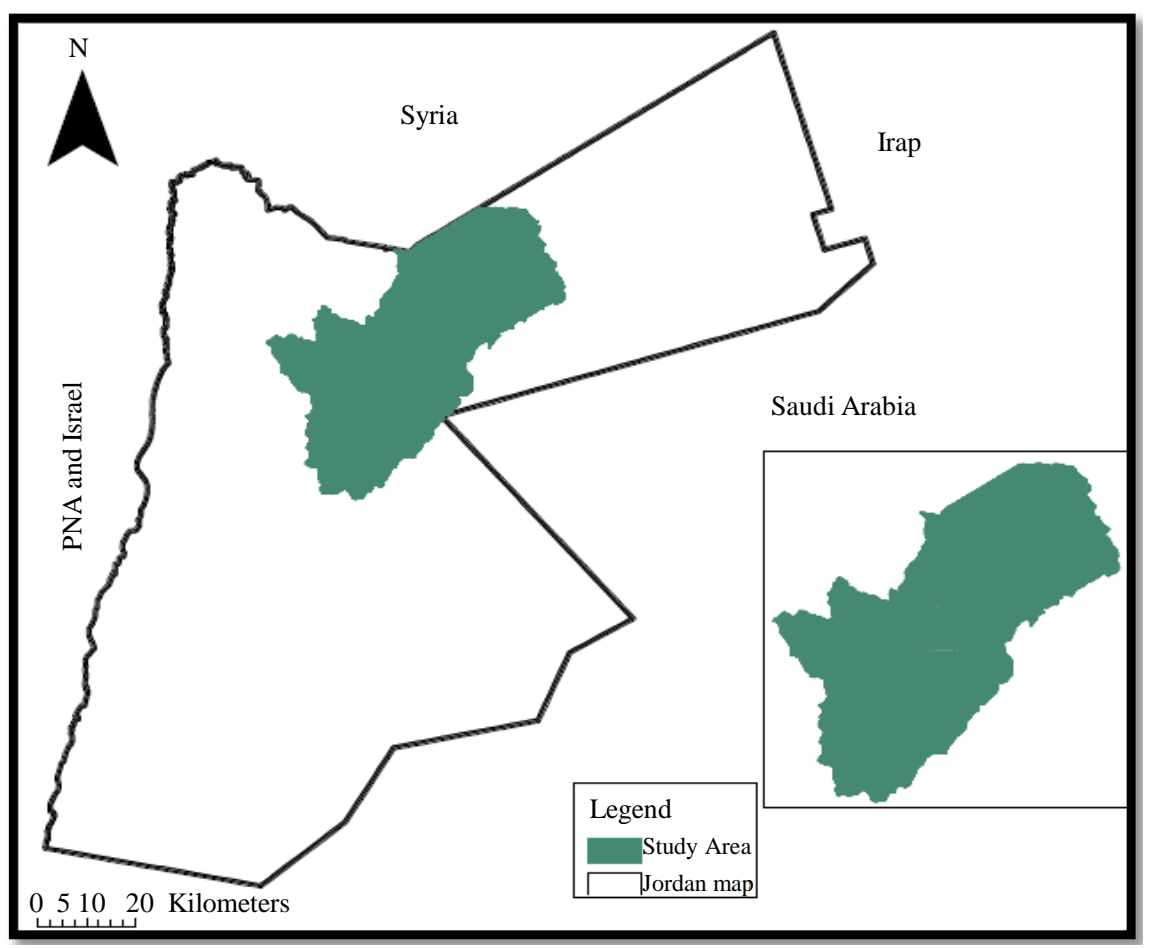

Figure 2. Study area (Azraq basin).

Weighted linear combination (WLC) is a major technique used for site selection within GIS environment. The use of the WLC method for the selection of potential sites for water harvesting has been widely used over the last years. Many of the studies use a WLC method in a GIS environment for the selection of potential sites for water harvesting such as [2] [4] [7] [10]-[13].

Boolean technique, based on the variables are either true or false. The use of Boolean method for identifying the optimum sites for water harvesting projects have been addressed in many studies [2] [3] [14] [15].

AHP is a method of MCDA that is implemented within GIS, which defines weights for criteria. AHP was initially developed by Saaty (1980). Several studies have been carried out for the determination of areas most suitable for groundwater recharge using AHP [16]-[22].

The AHP approach can be used as a set of tools for deriving weights of criteria. The AHP has the ability to deal with inconsistent judgments [23] [24].

The Pairwise Comparison Matrices PCMs involves comparing all the possible pairs of criteria in order to determine which of all the criteria is of a higher priority. The AHP method is based upon the construction of a series of PCMs, which compare all the criteria to one another. Saaty [1980] suggests a scale from 1 to 9 (Table 1) for PCM elements, where the value of 1 indicates that the criteria are equally important and a value of 9 indicates that the criterion under consideration is extremely important compared to the other criteria. PCM includes a consistency check where judgement errors are identified and a consistency ratio is calculated.

Three main stages to make decisions based on PCM in the AHP method operations [24] [25] are:

- The determination of the important criteria in the problem (water harvesting sites).

- The assessment of the relative importance of each criterion to each other. This is usually done by experts using a scale from 1 to 9. step includes three main operations [24] [25]:

- The assessment of the consistency through pairwise comparisons to assign the Consistency Ratio (CR). This stage involves the following operations [24] [25].

1) Calculating the priority vector for a criterion.

2) Computing $\lambda_{\max }$ (The Principal Eigenvalue).

3) Computing the Consistency index (CI).

4) Determining the appropriate value of the random consistency ratio (RI) by Table 2 .

5) Calculating CR. 
Table 1. Scales for the pairwise comparisons method, adapted from [23].

\begin{tabular}{|c|c|c|}
\hline Intensity of Importance & Definition & Explanation \\
\hline 1 & Equal importance in a pair & Two criteria contribute equally to the objective \\
\hline 3 & Moderate importance & Judgment and Experience slightly favour one criterion over another \\
\hline 5 & Strong importance & Judgment and Experience strongly favour one criterion over another \\
\hline 7 & Very strong importance & $\begin{array}{l}\text { Judgment and Experience very strongly favour one criterion over } \\
\text { another }\end{array}$ \\
\hline 9 & Extreme importance & $\begin{array}{l}\text { The evidence favouring one criterion over another is of highest } \\
\text { possible validity }\end{array}$ \\
\hline $2,4,6,8$ & Intermediate values & When compromise is needed \\
\hline Reciprocals & Values for inverse comparison & $\begin{array}{l}\text { If criterion } i \text { had one of the above numbers assigned to it when } \\
\text { compared with criterion } j \text {, then } j \text { has the reciprocal value when } \\
\text { compared with } i\end{array}$ \\
\hline
\end{tabular}

Table 2. Average random consistency indices (RI) for different number of criteria, adapted from [23].

\begin{tabular}{cccccccccccccccc}
\hline Number of criteria (N) & 1 & 2 & 3 & 4 & 5 & 6 & 7 & 8 & 9 & 10 & 11 & 12 & 13 & 14 & 15 \\
\hline $\begin{array}{c}\text { Random consistency } \\
\text { indices (RI) }\end{array}$ & 0 & 0.0 & 0.58 & 0.90 & 1.12 & 1.24 & 1.32 & 1.41 & 1.45 & 1.49 & 1.51 & 1.54 & 1.56 & 1.57 & 1.59 \\
\hline
\end{tabular}

\section{Adopted Selection Criteria}

There are many studies concerned with the water harvesting site selection using GIS. These studies were used in this research to define the water harvesting site selection criteria, together with the opinions of local experts. Based on these literatures [2]-[8] [12] [13] [26]-[30], six physical criteria were used in this research, which include the rainfall, the slope, the drainage density, the lineament density, the geology and the soil clay contents.

In addition, seven socio-economic factors are used along with the six criteria in this research to select the optimum sites for water harvesting in the study area. These socio-economic factors have been adopted in several researches [2]-[7] [28]. These factors include, the distances to the urban areas, the farm lands, the roads, the wells, the faults, the wadis and the international borders. These factors represent the major socio-economical activities in the study area. These seven factors were given a zero value for the excluded areas (not suitable) and a value of one for the included ones (suitable). The importance of these factors is:

\section{Selection of the Local Experts}

After defining the criteria for selecting sites for the water harvesting, the structured interview was undertaken with local experts. The interviews were carried out in November 2015. The questionnaire, shown in Table 3 was used to identify the relative importance of all the selected criteria. This questionnaire was based on the scale of 1 - 9 for the experts to assess the relative importance of each individual criterion. The interview was conducted with 5 experts from Al-al-Bayt university of Jordan that are relevant to the issues of the water harvesting. The background of experts covered the fields of geology, hydrogeology, civil engineering (water resources), groundwater and Geographic Information System (GIS). The experts were selected based on their knowledge of the study area and the water issue in Jordan in general and the study area in particular. Many of the experts had previously published their research [2] [3] [27] [31]-[33]. Interviews were conducted face to face.

Based on the literature review, the criteria were selected and subjected to a review by the local experts to determine the relative importance of each criterion. In this research, an analytic questionnaire survey was carried out to explore the opinions of the experts in the relative importance of the criteria selected for water harvesting using a scale of 1 to 9 . The analytic questionnaire was used to check the consistency ratio (CR) and identify the weights for the selected criteria. This involved interviewing the water experts and collecting specific data about the criteria.

\section{Data Collection}

The selection sites for the water harvesting require the availability of suitable data; these are both secondary and 
Table3. A sample from the questionnaire used to determine the relative importance of criteria.

\begin{tabular}{|c|c|c|c|c|c|c|c|c|c|c|c|c|c|c|c|c|c|c|}
\hline \multirow{2}{*}{ Criteria } & \multicolumn{7}{|c|}{ More importance } & \multicolumn{2}{|r|}{ Equal importance } & \multicolumn{8}{|c|}{ Less importance } & \multirow{2}{*}{ Criteria } \\
\hline & 9 & 8 & 7 & 6 & 5 & 4 & 3 & 2 & 1 & 2 & 3 & 4 & 5 & 6 & 7 & 8 & 9 & \\
\hline Rainfall & & & & & & & & & & & & & & & & & & Rainfall \\
\hline Slope & & & & & & & & & & & & & & & & & & Slope \\
\hline Soil Clay contents & & & & & & & & & & & & & & & & & & Soil Clay contents \\
\hline Lineament Density & & & & & & & & & & & & & & & & & & Lineament Density \\
\hline Geology & & & & & & & & & & & & & & & & & & Geology \\
\hline Drainage Density & & & & & & & & & & & & & & & & & & Drainage Density \\
\hline
\end{tabular}

primary data. the primary data is interviews with experts. The secondary data are collected from various national organizations working in the Jordan. These data are digital maps and other data for different physical and socio-economic aspects of the study area. Table 4 shows the major GIS layers used in this research.

\section{Data Analysis of Research}

\subsection{AHP Analysis}

Consistency ratio (CR) is calculated using Pairwise Comparison (PWC) technique to assess the consistency between the acquired experts' opinions. PWC was applied to check that the weights for the selection criteria given by the experts are consistent. The traditional implementation of AHP is used in this study [24] [34]-[37].

CR was calculated for all the acquired experts opinions to check if it is less than or equal to 0.1 , thereby to check the suitability of each pairwise comparison matrix for the AHP analysis.

The results of the conducted questionnaire are summarised in Table 5. The experts' opinions were selected according to the scale 1 - 9, and then the Pairwise Comparison Method (PCM) was applied within the Analytical Hierarchical Process (AHP) to check the CR and to identify the final weights for each criterion. The results of the PWCM (Weights, $\lambda_{\max }$, CI, RI and CR) is summarised in Table 6.

The CR was less the 0.1 for the pairwise comparison metrics of the experts' evaluation of the site selection criteria represents the consistency ratio of the opinions of the experts. Since the calculated CR is less than or equal to 0.1 for all the experts weightings, this indicates that the acquired experts opinions are consistent, and are suitable for the implementation of the AHP analysis.

\subsection{Site Selection Criteria (Weights and Rating)}

To identify the potential sites for the water harvesting, site selection depends on the rating and the weights of each thematic layer. As stated in this research, opinions of interviewed experts were used to determine the weights of each site selection criterion for the water harvesting and the Analytical Hierarchy Process (AHP) approach used to assess the consistency of the expert opinions by using the consistency ratio(CR), which should be less than or equal to 0.1 .

The rating of six physical criteria was selected based on a review of the literature. Using the WLC technique, the rate was assigned to each criterion in the scale of 1 to 4 . This is the scale adopted by most of the related literature to date. Table 7 summarizes (weights and rating) the selection criteria for water harvesting projects within the study area.

As discussed in this research, seven implementations representative of socio-economic factors (Table 8) were taken into account (the international border, wadis, roads, urban areas, faults, wells and farms). These layers were multiplied together after being converted into raster format in ArcGIS. The buffers were then applied on the factors as listed previously. Then, 0 and 1 values were added to the new map containing all the buffered zones. This map was then converted to raster format.

\subsection{Physical Criteria Analysis}

Six physical criteria were used in the research for selecting the suitable sites for the water harvesting recharge are: rainfall, slope, soil clay contents, drainage density, lineament density and Geology. Weights and ratings 
Table 4. Secondary data used in this research and their sources.

\begin{tabular}{ccc}
\hline GIS layer & Scale & Source \\
\hline Rainfall & $1: 250,000$ & Higher Council for Science and Technology (2007) \\
Lineament & $1: 250,000$ & \\
Drainage (Wadi) & $1: 250,000$ & \\
Urban (Town and Villages) & $1: 250,000$ & Royal Jordanian Geographic Centre (1995) \\
Roads & $1: 250,000$ & \\
Geology & $1: 250,000$ & \\
Fault & $1: 250,000$ & Jordan Ministry of Agriculture (1993) \\
Farms & $1: 250,000$ & Water Authority of Jordan, (2012) \\
Soil clay contents & $1: 750,000$ & United States Geological Survey (USGS) (2011) \\
Wells & Well Data (Excel File) & \\
\hline
\end{tabular}

Table 5. The pairwise comparison matrix of experts opinions.

\begin{tabular}{|c|c|c|c|c|c|c|}
\hline Criteria & Rainfall & Slope & Lineament Density & Drainage density & Geology & Soil Clay contents \\
\hline Rainfall & 1 & 1 & 2 & 2 & 2 & 2 \\
\hline Slope & 1 & 1 & 2 & 2 & 1 & 1 \\
\hline Lineament Density & 0.5 & 0.5 & 1 & 2 & 1 & 1 \\
\hline Drainage density & 0.5 & 0.5 & 0.5 & 1 & 1 & 2 \\
\hline Geology & 0.5 & 1 & 1 & 1 & 1 & 0.5 \\
\hline Soil Clay contents & 0.5 & 1 & 1 & 0.5 & 2 & 1 \\
\hline
\end{tabular}

Table 6. The computed values of weights (priority vector), CI, RI and CR for experts opinions.

\begin{tabular}{|c|c|c|c|c|c|}
\hline Criteria & Weights (priority vector) & $\lambda \max$ & CI & RI & CR \\
\hline Rainfall & 0.245 & \multirow{6}{*}{6.75} & \multirow{6}{*}{0.15} & \multirow{6}{*}{1.24} & \multirow{6}{*}{0.1} \\
\hline Slope & 0.202 & & & & \\
\hline Lineament Density & 0.142 & & & & \\
\hline Drainage density & 0.133 & & & & \\
\hline Geology & 0.128 & & & & \\
\hline Soil Clay contents & 0.150 & & & & \\
\hline
\end{tabular}

were given to each individual criterion as shown in Table 6. The WLC technique was used to integrate these physical criteria. The process of implementing the WLC technique includes standardising the suitability maps, assigning weights of relative importance to the suitability maps, then combining the weights and the standardised suitability maps and obtaining a suitability map.

All the generated thematic layers were integrated in ArcGIS ${ }^{\circledR}$ in order to derive a map depicting the suitable areas for the water harvesting of the study area. The total weight of each map of the final integrated layer was computed using Equation 5:

$$
\mathrm{Si}=(\mathrm{Rw} \cdot \mathrm{Rr})+(\mathrm{SLw} \cdot \mathrm{SLr})+(\mathrm{SCw} \cdot \mathrm{SCr})+(\mathrm{LDw} \cdot \mathrm{LDr})+(\mathrm{DDw} \cdot \mathrm{DDr})+(\mathrm{Gw} \cdot \mathrm{Gr})
$$

where, "w” represents the weight of each criterion, and " $r$ " represents the rating of each criterion namely: Rainfall (R), Slope (SL), Lineament Density (LD), Soil Clay contents (SC), Drainage Density (DD) and Geology (G). ' $\mathrm{Si}$ ' is the water harvesting index, which is a dimensionless number that identifies the suitable sites for the water harvesting in the area. 
Table 7. The rating of the six criteria selected based on literature review and weights (After 2).

\begin{tabular}{|c|c|c|c|}
\hline Criteria & Weight & Condition & Rating \\
\hline \multirow{4}{*}{ Rainfall } & \multirow{4}{*}{0.245} & $\geq 500$ & 4 \\
\hline & & $500>\mathrm{R} \geq 300$ & 3 \\
\hline & & $300>\mathrm{R} \geq 100$ & 2 \\
\hline & & $<100$ & 1 \\
\hline \multirow{4}{*}{ Slope } & \multirow{4}{*}{0.202} & $<3$ & 4 \\
\hline & & $5>S \geq 3$ & 3 \\
\hline & & $10>S \geq 5$ & 2 \\
\hline & & $>10$ & 1 \\
\hline \multirow{4}{*}{ Soil Clay contents } & \multirow{4}{*}{0.15} & $\geq 35 \%$ & 4 \\
\hline & & $35>C \geq 18$ & 3 \\
\hline & & $18>C \geq 10$ & 2 \\
\hline & & $<10$ & 1 \\
\hline \multirow{4}{*}{$\begin{array}{l}\text { Drainage density } \\
(\mathrm{Km} / \mathrm{sq} . \mathrm{Km})\end{array}$} & \multirow{4}{*}{0.133} & $>2.55$ & 4 \\
\hline & & $2.55>\mathrm{D} \geq 1.5$ & 3 \\
\hline & & $1.5>\mathrm{D} \geq 0.75$ & 2 \\
\hline & & $<0.75$ & 1 \\
\hline \multirow{4}{*}{ Lineament Density } & \multirow{4}{*}{0.142} & $0<\mathrm{L} \leq 1.5$ & 4 \\
\hline & & $1.5<\mathrm{L} \leq 2.5$ & 3 \\
\hline & & $2.5<\mathrm{L} \leq 3.5$ & 2 \\
\hline & & $>3.5$ & 1 \\
\hline \multirow{4}{*}{ Geology } & \multirow{4}{*}{0.128} & Chalky marl, Marl, Limestone & 4 \\
\hline & & Limestone, dolomitic limestone & 3 \\
\hline & & Limestone, Chalk, Chert & 2 \\
\hline & & Basalt & 1 \\
\hline
\end{tabular}

Table 8. Water harvesting selection factors [2]-[4] [7] [28] [30].

\begin{tabular}{|c|c|c|}
\hline Factors & Condition & Value \\
\hline \multirow{2}{*}{ Distance to international border } & $>1000$ & 1 \\
\hline & $\leq 1000$ & 0 \\
\hline \multirow{2}{*}{ Distance to wadis meters } & $>50$ & 1 \\
\hline & $\leq 50$ & 0 \\
\hline \multirow{2}{*}{ Roads meter } & $>250$ & 1 \\
\hline & $\leq 250$ & 0 \\
\hline \multirow{2}{*}{ Urban } & $>250$ & 1 \\
\hline & $\leq 250$ & 0 \\
\hline \multirow{2}{*}{ Faults } & $>1000$ & 1 \\
\hline & $\leq 1000$ & 0 \\
\hline \multirow{2}{*}{ Wells } & $>500$ & 1 \\
\hline & $\leq 500$ & 0 \\
\hline \multirow{2}{*}{ Farms } & $>250$ & 1 \\
\hline & $\leq 250$ & 0 \\
\hline
\end{tabular}


As shown in Table 6, the six GIS layers representing the physical criteria were subjected to a GIS analysis in order to select the optimum sites for the water harvesting in the study area based on these criteria. All maps, the following spatial data techniques were used:

- $\quad$ Updating attribute tables according to Table 6

- $\quad$ Converted to a raster format

- $\quad$ Slope derivation

- $\quad$ Raster reclassification

- Raster calculation (integrated to produce the optimum sites for the water harvesting within the study area (Figure 3 and Figure 4)).

\subsection{Water Harvesting Site Selection Based on the WLC Analysis}

According to Equation (1), six thematic layers were added using the WLC method and were classified into five classes of potential water harvesting in the study area, including very low suitability, low suitability, moderate suitability, high suitability, and very high suitability for water harvesting. These thematic layers were integrated to generate a water harvesting suitability map of the study area as shown in Figure 5.

\subsection{Socio-Economic Criteria}

Seven socio-economic criteria (factors) were also integrated into the result shown above. All maps (factors), the following spatial data techniques were used:

- Buffering

- Union

- Updating attribute tables

- Raster reclassification

- $\quad$ Raster calculation (multiplication).

The buffer zones applied for each socio-economic criterion is based on the appropriate buffer distance listed in Table 7. Union in ArcGIS was used to spatially merge the buffer zones of each socio-economic criterion with the study area to incorporate the areas beyond the selected zone distances (Figure 6).

Boolean techniques were applied to the socio-economic factors that cannot be used as sites for water harvesting. The overlay of these factors is illustrated in Figure 7(r). In this figure all areas that are not suitable for harvesting are shown.

\subsection{Water Harvesting Suitability Mapping}

The WLC method was then used to integrate the generated suitability maps of the individual physical criterion in to a one suitability map for water harvesting in the study area. In addition, the Boolean method was used to eliminate the sites that are not suitable for a water harvesting, and generate an unsuitability map. The resultant maps (Figure 8) from the physical criteria, shown in Figure 5 integrated with the socio-economic criteria, shown in Figure 7(r). The study area was classified into five classes based on the minimum and maximum of the criteria maps, the following outcomes for all parts of the study area:

- $\quad$ No suitability areas, which represent $7 \%$ of the study area.

- Very low suitability, which represent $8 \%$ of the study area

- Moderate suitability, which represent $32 \%$ of the study area.

- $\quad$ High suitability areas, which represents $26 \%$ of the study area.

- Very high suitability areas, which represents $27 \%$ of the study area

Based on [27] [31] [33] [38], it is required to conduct the following steps to validate the outcomes of this research:

1) Surveying the suitable sites to establish if these sites are not occupied with other land uses of high socioeconomic values. This will help in preventing the selection of such sites that have not been known to the researcher when conducting the selection analysis.

2) Geophysical investigation to study the subsurface layers within the study area. This will help in determining wither these layers are suitable to establish a water harvesting schemes above these layers and.

3) Soil sampling from various locations within the study area to test the clay contents. This will help in validating the suitability of soils within the study area to establish water harvesting. 


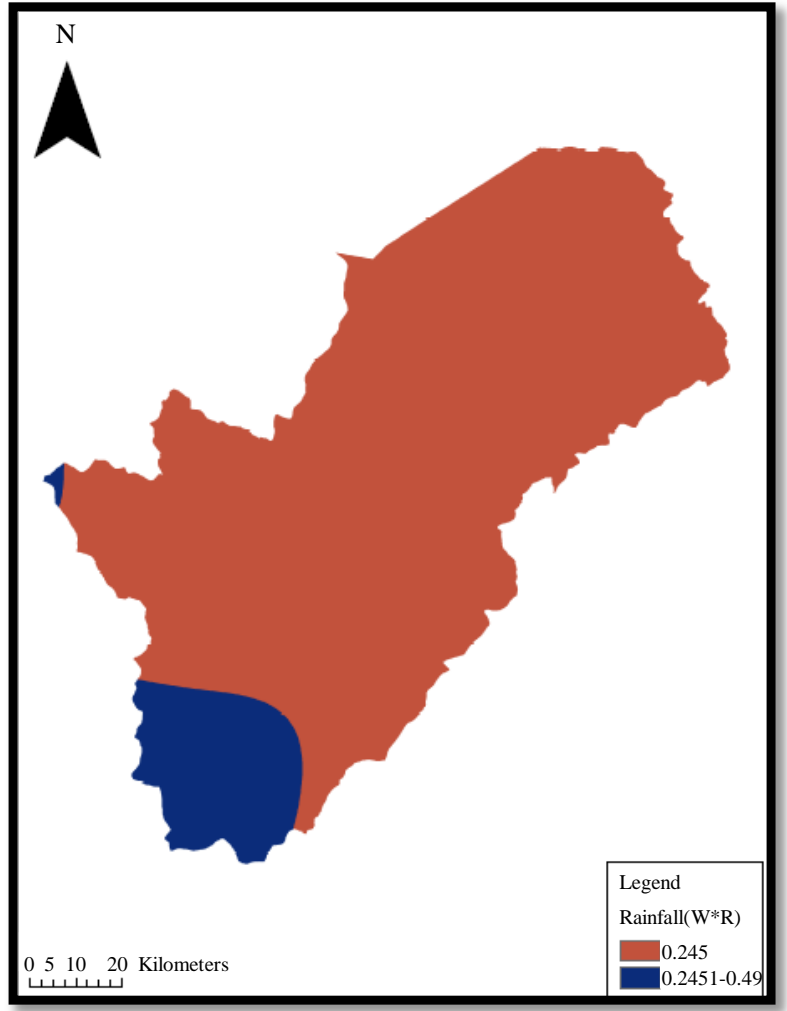

(a)

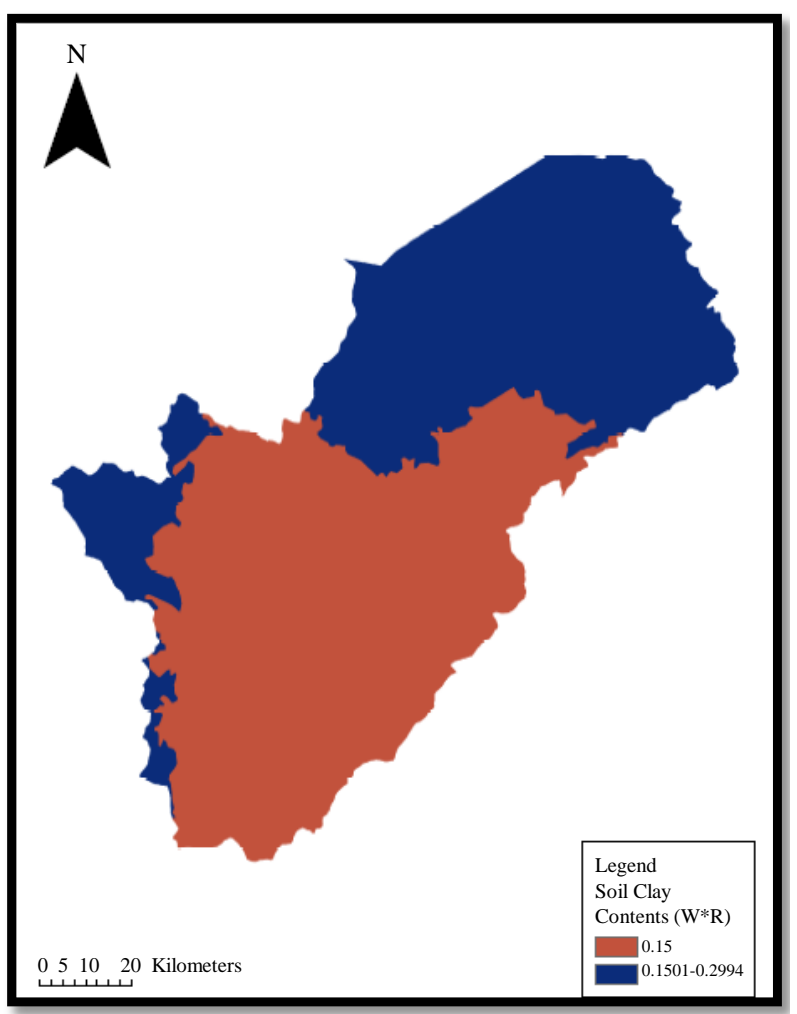

(c)

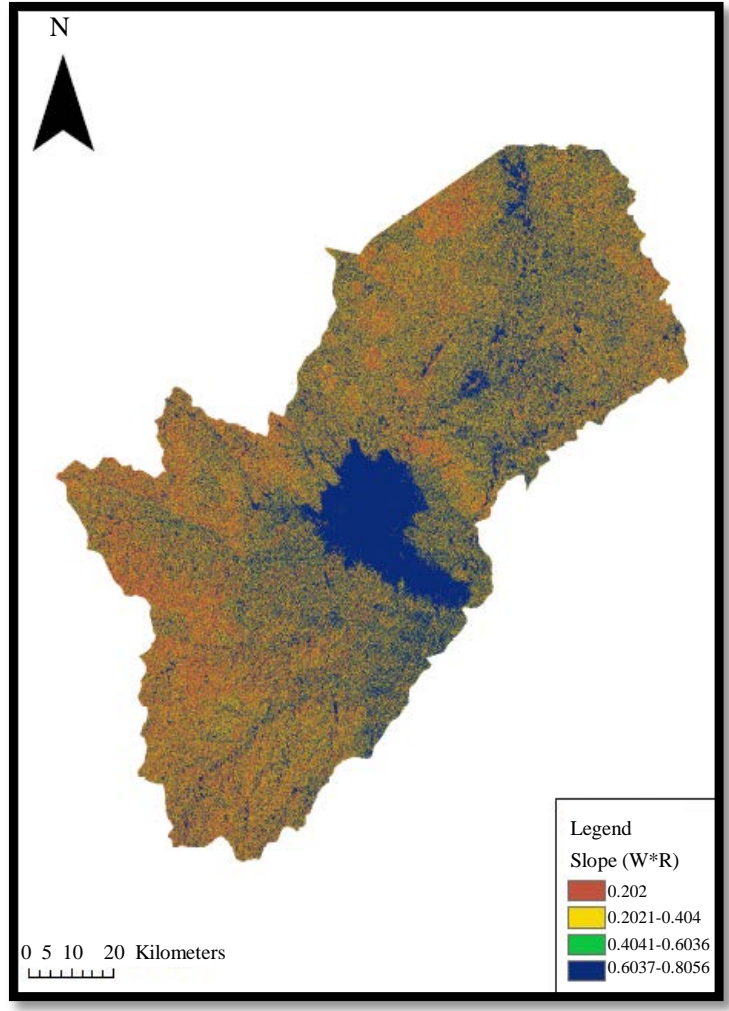

(b)

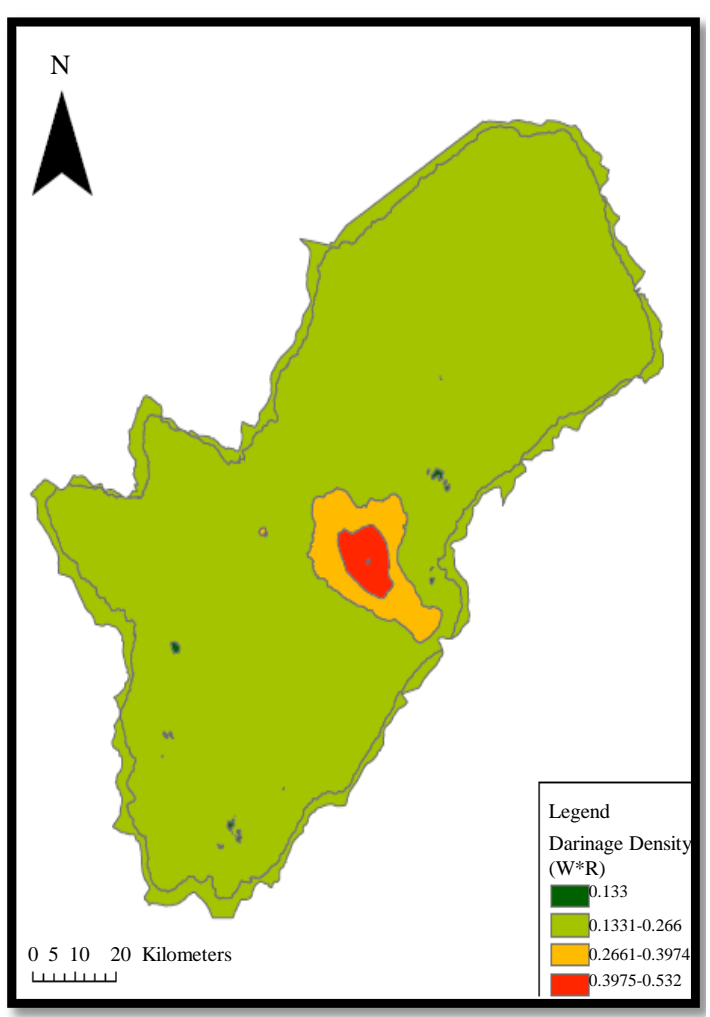

(d)

Figure 3. Rainfall suitability (a), Slope suitability (b), Soil Clay contents suitability (c), Drainage density suitability (d). 


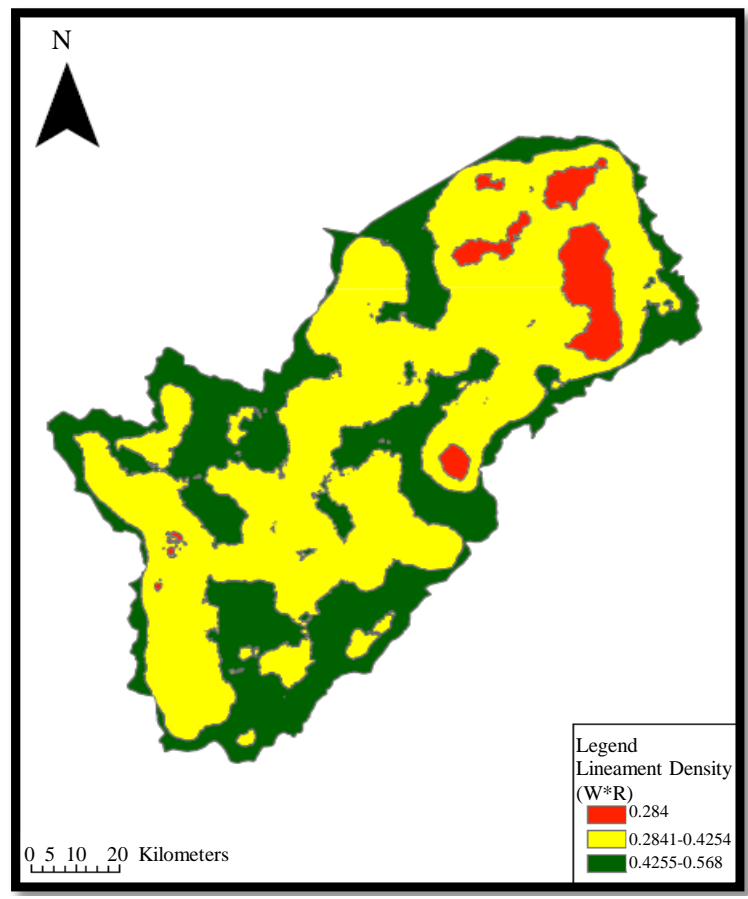

(e)

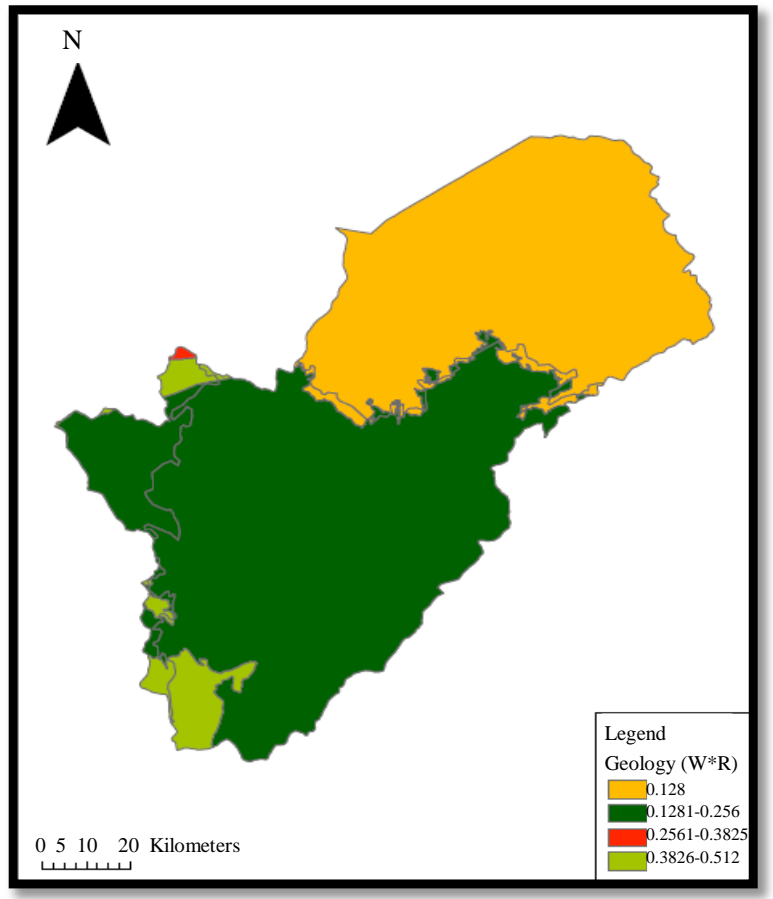

(f)

Figure 4. Lineament density suitability (e), Geology suitability (f).

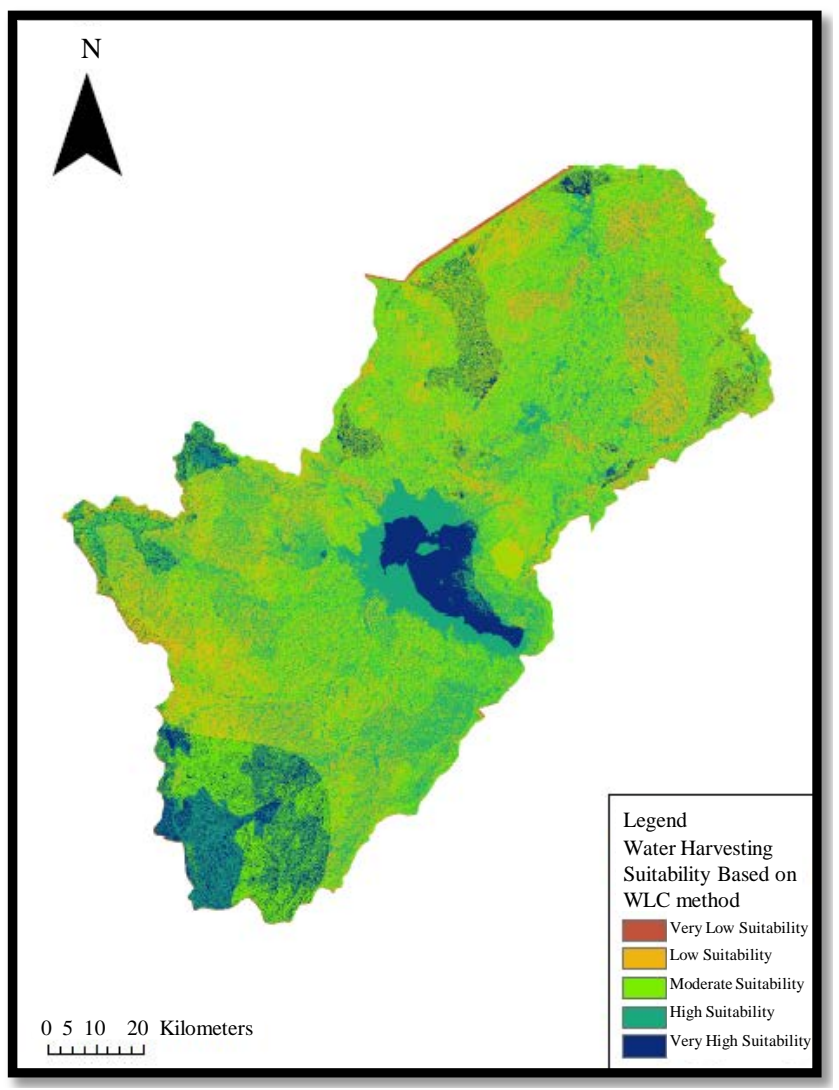

Figure 5. Suitability map for the water harvesting of the study area based on the WLC analysis. 


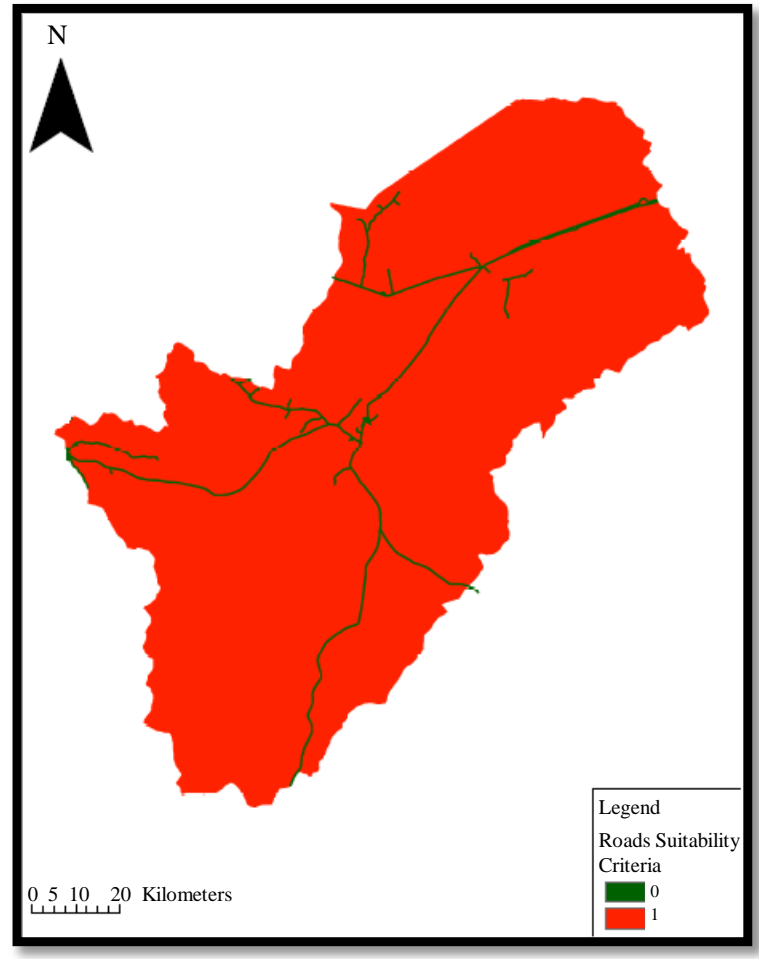

(g)

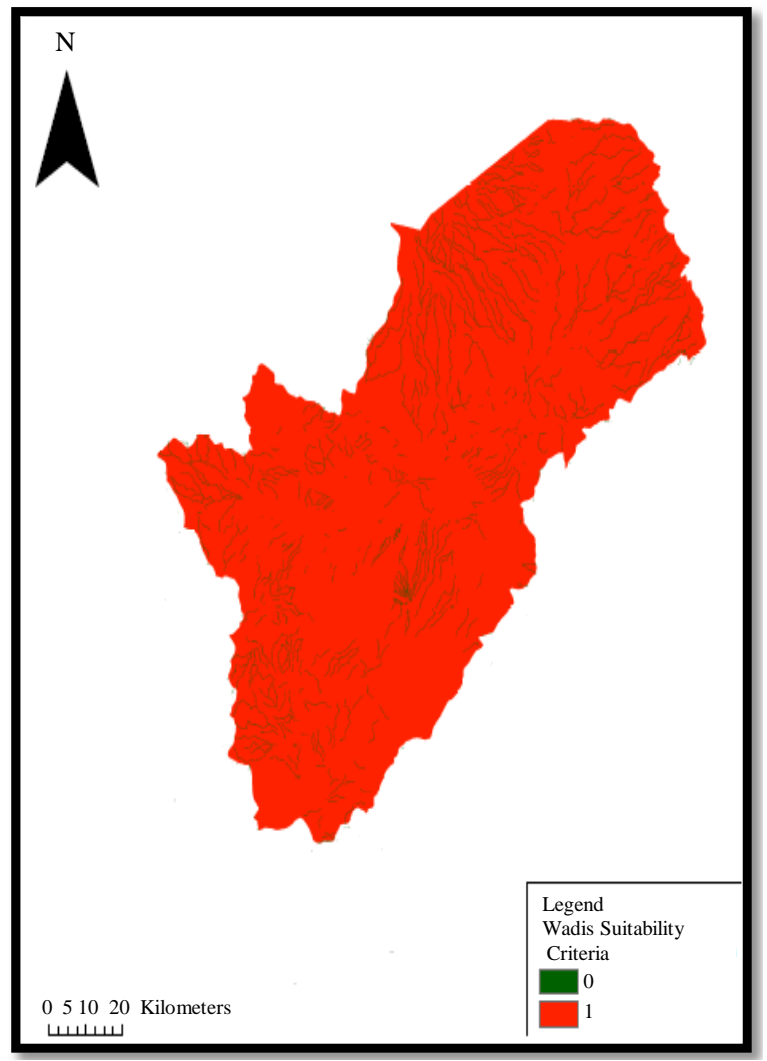

(k)

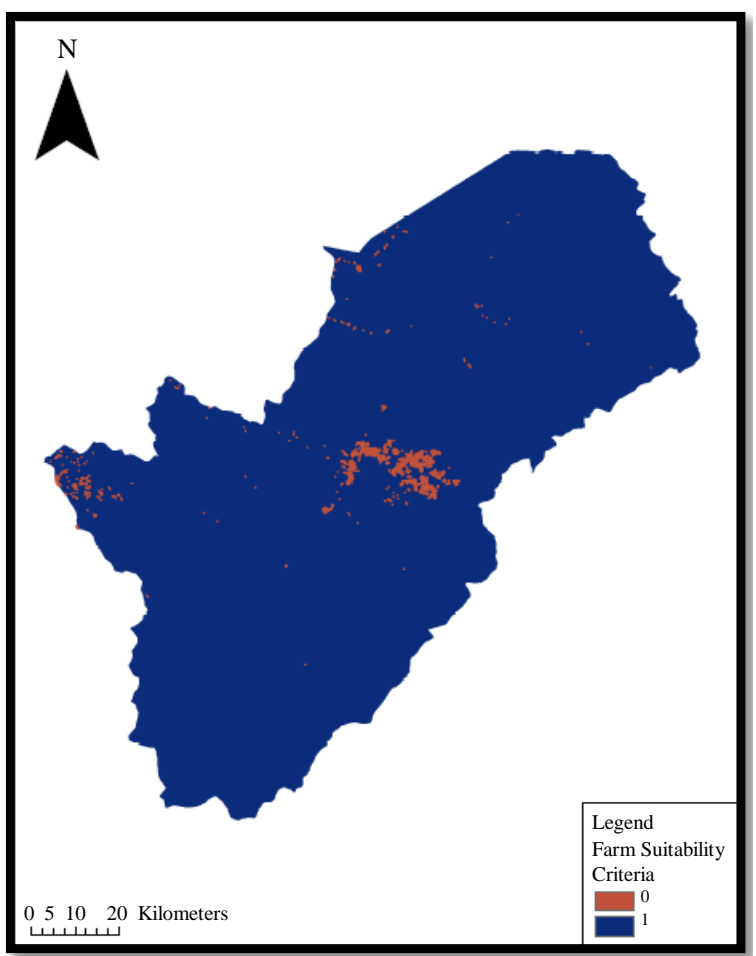

(h)

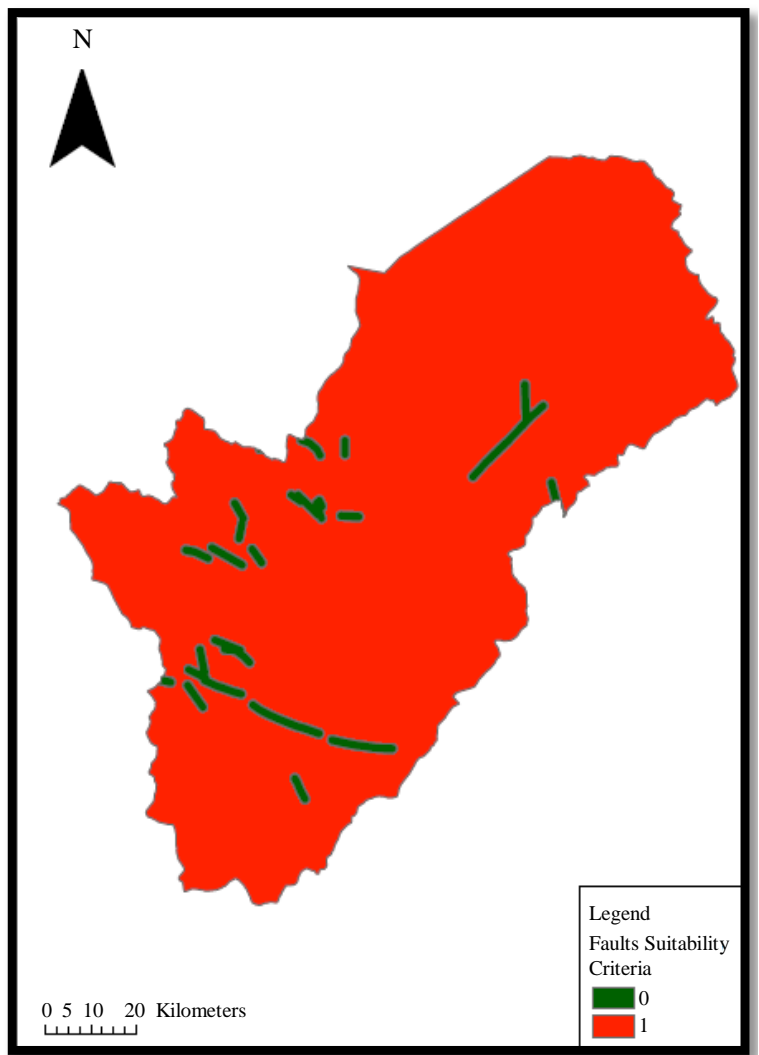

(1)

Figure 6. Roads buffer (g), Farms buffer (h), Wadis buffer (k), Faults buffer (l). 


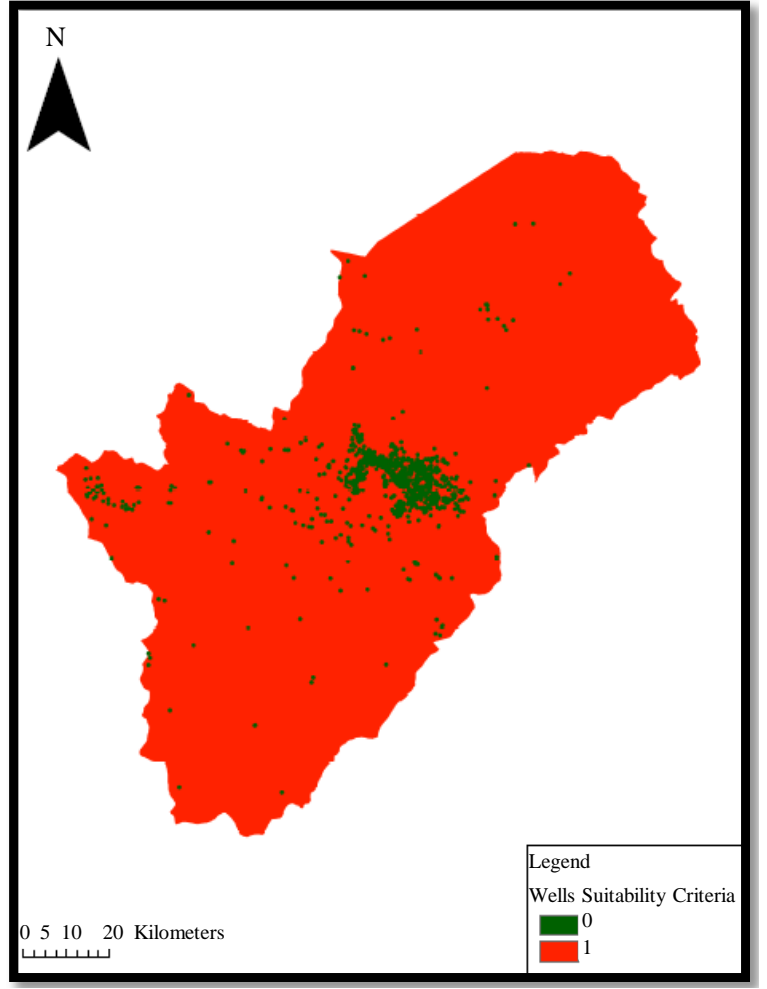

(m)

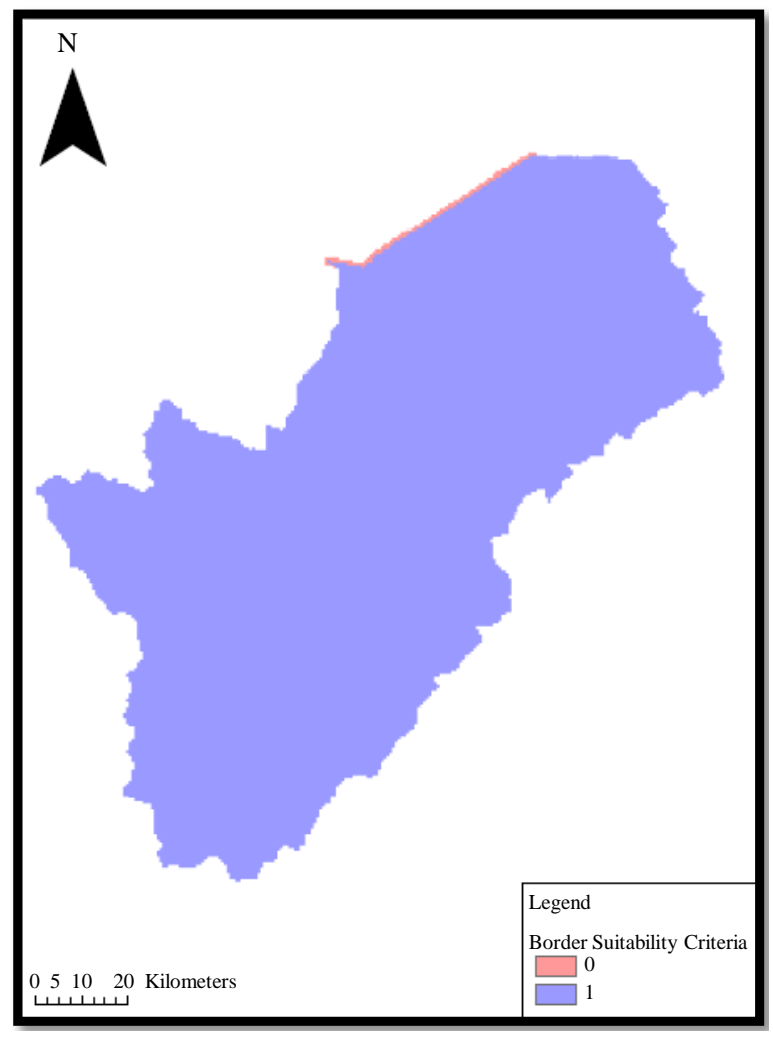

(o)

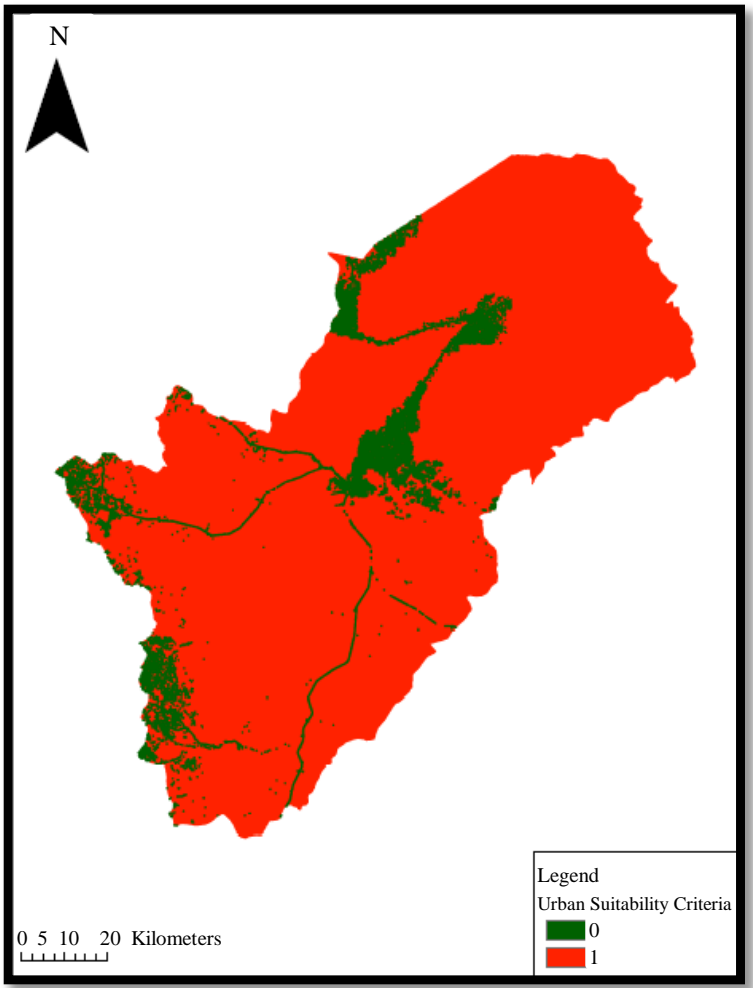

(n)

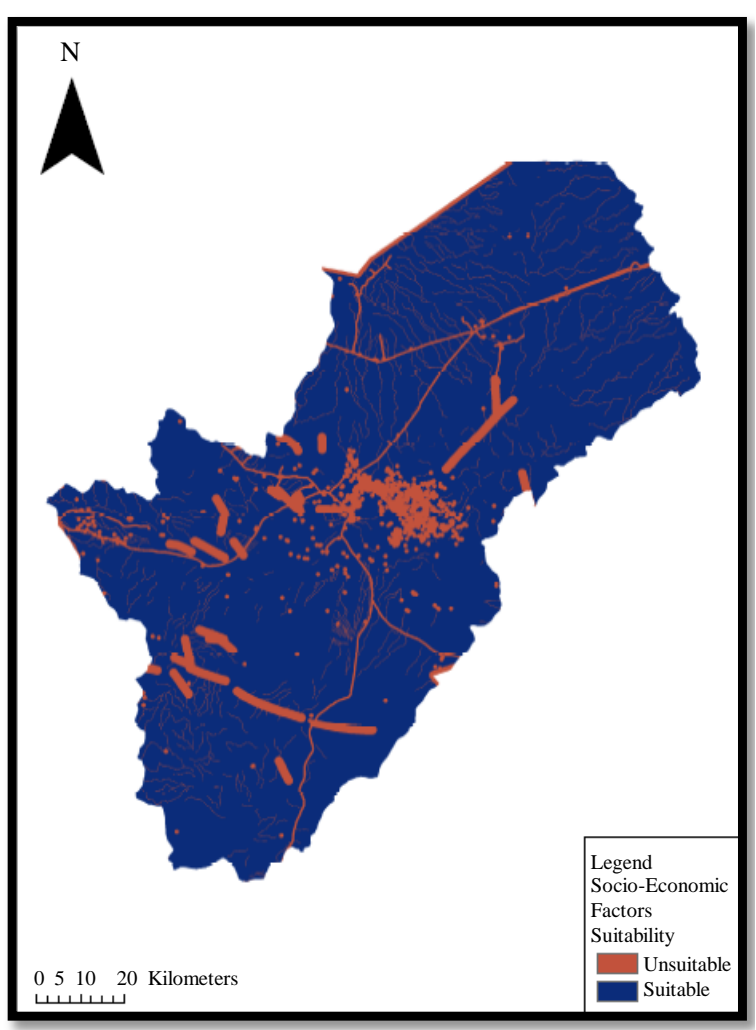

(r)

Figure 7. Wells buffer (m), Urban buffer (n), Border buffer (o), Unsuitable sites map (r). 


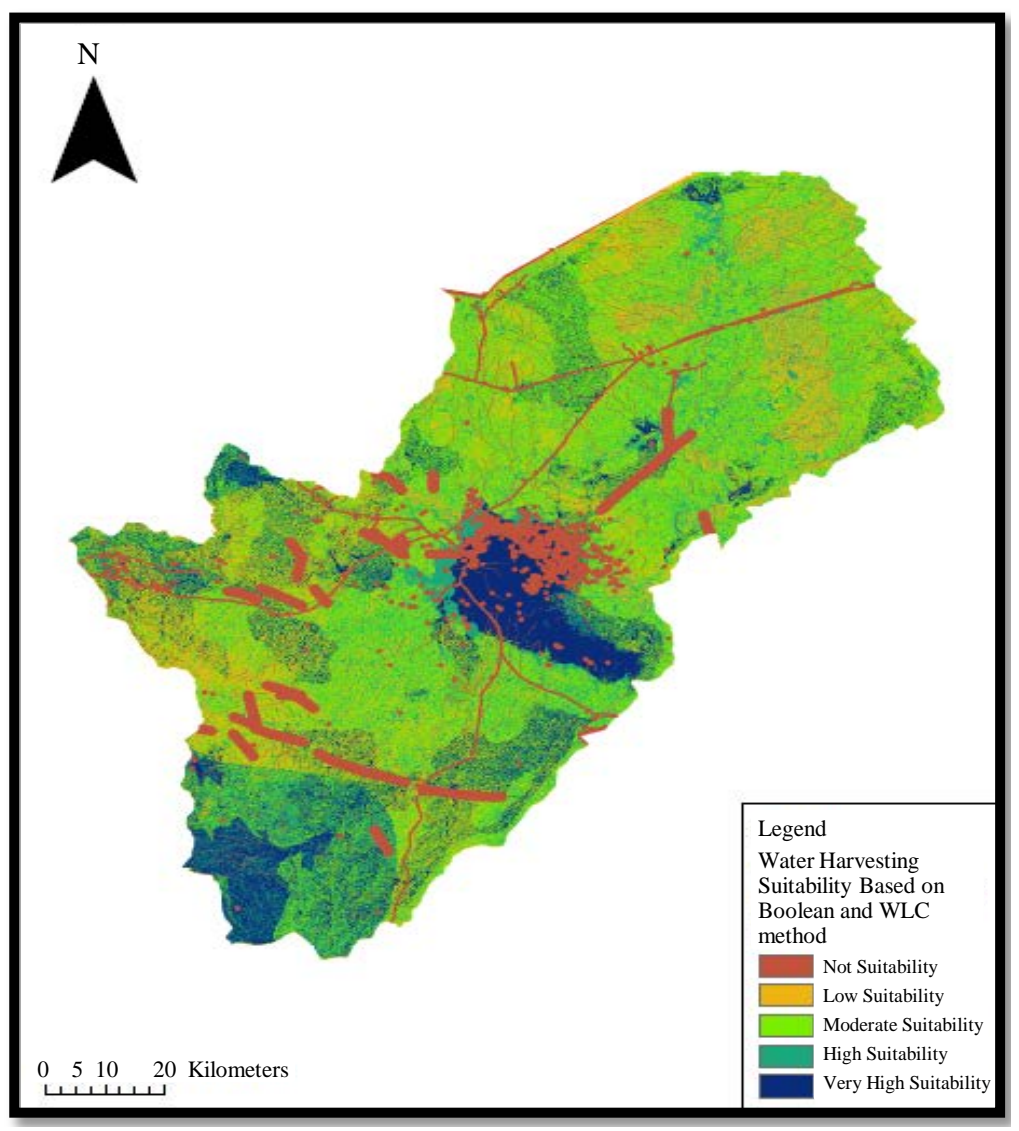

Figure 8. Final suitability map for water harvesting of the study area.

4) Calculate the watershed for the selected sites to determine the amount of runoff that could be utilised in these sites.

In this research, these steps were not conducted due to research fund limitation.

\section{Discussion and Conclusion}

In this study, Analytic Hierarchy Process (AHP) was used employed to generate a water harvesting suitability map of a study area located within the Jordan.

Six site selection criteria affecting the water harvesting in the study area were defined based on a literature review and discussions with relevant local experts (5 experts). These criteria were the Rainfall, Slope, Soil Clay contents, Drainage Density, Lineament Density and Geology. In addition, seven socio-economic factors that conflict with existing human activities, and thus, affecting the water harvesting were identified based on experts recommendations and literature review. These factors were the international border, wadis, roads, urban areas, faults, wells and farms.

It was found in this study that there was consistency in the experts' opinions by checking the consistency ratio (CR) for experts.

The Weighted Linear Combination (WLC) technique was used to identify the potential sites for water harvesting in the study area. This method is based on the collection of all the criteria after multiplying weights in rating, thereafter determining weights and unifying rating for each criterion. The study area was classified into five classes in terms of the suitability for the water harvesting namely: very low suitability for water harvesting, low suitability for water harvesting, moderately suitable for water harvesting, high suitability for water harvesting and very high suitability for water harvesting. The Boolean technique was then used to eliminate these sites that are not suitable for the water harvesting within the study area including the international border, wadis, roads, urban areas, faults, wells and farms. The Boolean operation resulted in classifying the study area into two 
classes, suitable and not suitable for water harvesting, where the specified sites categories that are not suitable for water harvesting are eliminated. To identify the optimal sites for water harvesting in the study area, the results of the WLC analysis and the results of the Boolean technique were integrated to generate a final water harvesting suitability map of the study area. The study area was classified into no suitability, low suitability, moderate suitability, high suitability, and very high suitability in terms of water harvesting.

This research will contribute to the enhancement of the available water resources in the country if the selected sites will be utilised for water harvesting. This will contribute to the sustainable socio-economic development of Jordan. It is recommend to conduct a field work to investigate the selected sites to test the suitability of soil and the sub-surface layers for water harvesting purposes.

\section{Acknowledgements}

I would like to express my deep gratitude to the interviewed experts: (Dr. Rida Al-Adamat, Dr. Abdullah Diabat, Dr. A'kif Al Fugara Dr. Saad Al Ayyash, Dr. Hani Al-Amoush for their contribution to this research and evaluating the site selection criteria.

\section{References}

[1] Jordan Ministry of Environment (2006) National Capacity Self-Assessment for Global Environmental Management (NCSA). http://www.thegef.org/gef/sites/thegef.org/files/documents/document/544.pdf

[2] Al-Adamat, R., Diabat, A. and Shatnawi, G. (2010) Combining GIS with Multicriteria Decision Making for Siting Water Harvesting Ponds in Northern Jordan. Journal of Arid Environments, 74, 1471-1477. http://dx.doi.org/10.1016/j.jaridenv.2010.07.001

[3] Al-Adamat, R. (2008) GIS as a Decision Support System for Siting Water Harvesting Ponds in the Basalt Aquifer/NE Jordan. Journal of Environmental Assessment Policy and Management, 10, 189-206. http://dx.doi.org/10.1142/S1464333208003020

[4] Baban, S.M. and Wan-Yusof, K. (2003) Modelling Optimum Sites for Locating Reservoirs in Tropical Environments. Water Resources Management, 17, 1-17. http://dx.doi.org/10.1023/A:1023066705226

[5] El-Awar, F., Makke, M., Zurayk, R. and Mohtar, R. (2000) A Hydro-Spatial Hierarchical Method for Siting Water Harvesting Reservoirs in Dry Areas. Applied Engineering in Agriculture, 16, 395-404. http://dx.doi.org/10.13031/2013.5223

[6] Gupta, K., Deelstra, J. and Sharma, K. (1997) Estimation of Water Harvesting Potential for a Semiarid Area Using GIS and Remote Sensing. In: Baumgartner, F.M., Schultz, A.G. and Johnson, I.A., Eds., Remote Sensing and Geographic Information Systems for Design and Operation of Water Resources Systems (Proceedings of Rabat Symposium S3, April 1997). IAHS Publ. No. 242, 53-62.

[7] Shatnawi, G. (2006) Determine the Best Sites for Water Harvesting Projects (Dams and Hafirs) in Northeastern Badia Using GIS Applications. Unpublished M.Sc. Thesis, Al al-Bayt University, Jordan.

[8] Srivastava, R. (1996) Methodology for Optimizing Design of Integrated Tank Irrigation System. Journal of Water Resources Planning and Management, 122, 394-402. http://dx.doi.org/10.1061/(ASCE)0733-9496(1996)122:6(394)

[9] Ayalew, L. and Yamagishi, H. (2005) The Application of GIS-Based Logistic Regression for Landslide Susceptibility Mapping in the Kakuda-Yahiko Mountains, Central Japan. Geomorphology, 65, 15-31. http://dx.doi.org/10.1016/j.geomorph.2004.06.010

[10] Hajkowicz, S. and Higgins, A. (2008) A Comparison of Multiple Criteria Analysis Techniques for Water Resource Management. European Journal of Operational Research, 184, 255-265. http://dx.doi.org/10.1016/j.ejor.2006.10.045

[11] Vorhauer, C.F. and Hamlett, J.M. (1996) GIS: A Tool for Siting Farm Ponds. Journal of Soil and Water Conservation, 51, 434-438.

[12] Malczewski, J. (2004) GIS-Based Land-Use Suitability Analysis: A Critical Overview. Progress in Planning, 62, 3-65.

[13] Price, M. (1996) Introducing Groundwater. Routledge, Boston, London. http://dx.doi.org/10.1007/978-1-4615-1811-2

[14] Yalcin, A. (2008) GIS-Based Landslide Susceptibility Mapping Using Analytical Hierarchy Process and Bivariate Statistics in Ardesen (Turkey): Comparisons of Results and Confirmations. Catena, 72, 1-12. http://dx.doi.org/10.1016/j.catena.2007.01.003

[15] Madrucci, V., Taioli, F. and de Araújo, C.C. (2008) Groundwater Favorability Map Using GIS Multicriteria Data Analysis on Crystalline Terrain, Saeo Paulo State, Brazil. Journal of Hydrology, 357, 153-173.

http://dx.doi.org/10.1016/j.jhydrol.2008.03.026 
[16] Longdill, P.C., Healy, T.R. and Black, K.P. (2008) An Integrated GIS Approach for Sustainable Aquaculture Management Area Site Selection. Ocean \& Coastal Management, 51, 612-624. http://dx.doi.org/10.1016/j.ocecoaman.2008.06.010

[17] Anane, M., Kallali, H., Jellali, S. and Ouessar, M. (2008) Ranking Suitable Sites for Soil Aquifer Treatment in Jerba Island (Tunisia) Using Remote Sensing, GIS and AHP-Multicriteria Decision Analysis. International Journal of Water, 4, 121-135. http://dx.doi.org/10.1504/IJW.2008.018151

[18] Han, Z. (2003) Groundwater Resources Protection and Aquifer Recovery in China. Environmental Geology, 44, 106111.

[19] Krishnamurthy, J. and Srinivas, G. (1995) Role of Geological and Geomorphological Factors in Ground Water Exploration: A Study Using IRS LISS Data. International Journal of Remote Sensing, 16, 2595-2618. http://dx.doi.org/10.1080/01431169508954579

[20] Krishnamurthy, J., Venkatesa Kumar, N., Jayaraman, V. and Manivel, M. (1996) An Approach to Demarcate Ground Water Potential Zones through Remote Sensing and a Geographical Information System. International Journal of Remote Sensing, 17, 1867-1884. http://dx.doi.org/10.1080/01431169608948744

[21] Rahman, M.A., Rusteberg, B., Gogu, R., Lobo Ferreira, J. and Sauter, M. (2012) A New Spatial Multi-Criteria Decision Support Tool for Site Selection for Implementation of Managed Aquifer Recharge. Journal of Environmental Management, 99, 61-75. http://dx.doi.org/10.1016/j.jenvman.2012.01.003

[22] Rolland, A. and Rangarajan, R. (2013) Runoff Estimation and Potential Recharge Site Delineation Using Analytic Hierarchy Process. Geocarto International, 28, 159-170. http://dx.doi.org/10.1080/10106049.2012.665499

[23] Saraf, A. and Choudhury, P. (1998) Integrated Remote Sensing and GIS for Groundwater Exploration and Identification of Artificial Recharge Sites. International Journal of Remote Sensing, 19, 1825-1841. http://dx.doi.org/10.1080/014311698215018

[24] Saaty, T.L. (1980) The Analytic Hierarchy Process: Planning, Priority Setting, Resources Allocation. McGraw-Hill, New York.

[25] Malczewski, J. (1999) GIS and Multicriteria Decision Analysis. John Wiley and Sons, New York.

[26] Eastman, J. (1997) Idrisi for Windows, User’s Guide, Version 2.0: Clark Labs for Cartographic Technology and Geographic Analysis. Clark University, Worcester.

[27] Saaty, T.L. (1977) A Scaling Method for Priorities in Hierarchical Structures. Journal of Mathematical Psychology, 15, 234-281. http://dx.doi.org/10.1016/0022-2496(77)90033-5

[28] Alayyash, S., Al-Adamat, R., Al-Amoush, H., Al-Meshan, O., Rawjefih, Z., Shdeifat, A., Al-Harahsheh, A. and Al-Farajat, M. (2012) Runoff Estimation for Suggested Water Harvesting Sites in the Northern Jordanian Badia. Journal of Water Resource and Protection, 4, 127-132. http://dx.doi.org/10.4236/jwarp.2012.43015

[29] Yang, Y.D. (2003) Application of GIS and Remote Sensing for Assessing Watershed Ponds for Aquaculture Development in Thai Nguyen, Vietnam. http://www.gisdevelopment.net

[30] Critchley, W., Siegert, K. and Chapman, C. (1991) Water Harvesting, A Manual Guide for the Design and Construction of Water Harvesting Schemes for Plant Production. FAO, Rome. www.fao.org/docrep/u3160e/u3160e07.htm

[31] Al-Adamat, R. (2012) The Use of GIS and Google Earth for Preliminary Site Selection of Groundwater Recharge in the Azraq Oasis Area-Jordan. Journal of Water Resource and Protection, 4, 395-399. http://dx.doi.org/10.4236/jwarp.2012.46045

[32] Al-Adamat, R., Rawajfih, Z., Easter, M., Paustian, K., Coleman, K., Milne, E., Falloon, P., Powlson, D. and Batjes, N. (2007) Predicted Soil Organic Carbon Stocks and Changes in Jordan between 2000 and 2030 Made Using the GEFSOC Modelling System. Agriculture, Ecosystems and Environment, 122, 35-45. http://dx.doi.org/10.1016/j.agee.2007.01.006

[33] Al-Amoush, H., Al-Adamat, R., Alayyash, S. and Al-Meshan, O. (2012) Preliminary Geophysical Investigation for Suggested Water Harvesting Sites in the Northern Jordanian Badia. Research Journal of Environmental and Earth Sciences, 4, 560-569.

[34] Saaty, T.L. (1990) How to Make a Decision: The Analytic Hierarchy Process. European Journal of Operational Research, 48, 9-26. http://dx.doi.org/10.1016/0377-2217(90)90057-I

[35] Al-Harbi, K.M. (2001) Application of the AHP in Project Management. International Journal of Project Management, 19, 19-27. http://dx.doi.org/10.1016/S0263-7863(99)00038-1

[36] Mendoza, G., Macoun, P., Prabhu, R., Sukadri, D., Purnomo, H. and Hartanto, H. (1999) Guidelines for Applying Multi-Criteria Analysis to the Assessment of Criteria and Indicators. Criteria and Indicators Toolbox Series No. 9, Center for International Forestry Research (CIFOR), Bogor, 1-85. 
[37] Ozturk, D. and Batuk, F. (2011) Implemntation of GIS-Based Multicriteria Decision Analysis with VB in ArcGIS. International Journal of Information Technology and Decision Making, 10, 1023-1042. http://dx.doi.org/10.1142/S0219622011004695

[38] Al-Shabeeb, A.R.R. (2015) Amodified Analytical Hierarchry Process Methods to Select Sites for Groundwater Recharge in Jordan. Unpublished PhD Thesis, Leicester University, Leicester, 204 p. 